\title{
Clone Fertility and Genetic Diversity in a Black Pine Seed Orchard
}

\author{
By M. ERTEKIN ${ }^{1)}$
}

(Received 24 ${ }^{\text {th }}$ December 2008)

\begin{abstract}
Clonal variation in the number of female and male strobili was studied for three consecutive years (2002-2004) in a clonal black pine seed orchard in Turkey. The data showed large differences in female and male fertility among clones in the three years. The correlation between female and male strobilus production was negative and statistically significant in 2004, a good-flowering year.

Clonal fertility and fertility variation, expressed by the sibling coefficient and coefficient of variation in strobilus production among 30 clones, were reported. Fertility varied among clones and among years, producing three-year averages of 99.3 and 801.6 for female and male strobili per ramet, respectively. Male fertility variation was higher than was female fertility variation in the three years.

The status number, a measure of genetic diversity, was calculated as 26.4 (2002), 23.9 (2003), and 24.0 (2004). On average, the relative status number, estimated based on total fertility, was $86 \%$ of the census number. Sexual asymmetry calculations showed that clonal contributions would be balanced between genders. Some management activities such as adjusting ramet number to balance clone contributions and mixing of seeds from consecutive years are suggested for the black pine seed orchard.
\end{abstract}

Key words: fertility variation, status number, genetic diversity, sexual asymmetry, Pinus nigra.

\section{Introduction}

Black pine (Pinus nigra Arnold. subsp. pallasiana (Lamb.) Holmboe) is among the most important native Pinus species and occupies about 3.3 million ha (16\%) of forest area in Turkey (ANONYMOUs, 2001a). It was identified as a priority species in the "National Tree Breeding and Seed Production Program" (KoskI and ANTOLA, 1994) and the "National Plan for In-situ Conservation of Plant Genetic Diversity" (KAYA et al., 1997). Silviculturally, it is considered one of the most important species and is extensively used in reforestation programs throughout the country. This investigation concentrated on the special race of black pine called "Camiyani", which is located in the Karabuk-Yenice region. It has a well-known valuable wood with a large ratio of core wood. Accordingly, demand has been high for wood of this race in this and other regions where it is found, and this has threatened the biological integrity of forest ecosystems. Therefore, existing genetic resources of this

\footnotetext{
1) University of Bartın, Faculty of Forestry, 74100 Bartın, Turkey. Tel. 90378223 5148, Fax: 903782235066.

E-Mail: muratertekin@hotmail.com
}

race have been protected by the General Directorate of Forest as a "Gene Conservation Area" whose seed orchard was established in Bartın, Turkey. Seed orchards are important seed sources for reforestation and have been demonstrated to be robust and to act as viable and reliable sources for the production of genetically improved seed for reforestation programs (ELKASSABY, 2000; KANG, 2001).

Maximal reproductive phenology synchronization and output equality, along with minimal inbreeding and pollen contamination are important first conditions for seed orchards to reach their expected theoretical genetic gain and diversity potential (KANG, 2001). Seed orchard investigations have focused on strobili production by clones (EL-KASSABY and ASKEW, 1991; HARJU, 1995). Large clonal differences in female and male fertility have been reported in seed orchards (KJAER, 1996; KANG and LindGren, 1998; NiKKANEN and RUOTSALAINEN, 2000; BILIR et al., 2002). Large genetic diversity in seed orchard crops can only be attained when all parents contribute similar amounts to the gamete pool. This assumption is virtually never fulfilled, and it is commonly observed that a small portion of orchard parents contributes a disproportionately large amount to the orchard crop (EL-KASSABY et al., 1989; EL-KASSABY and Cook, 1994). This unequal contribution leads to an accumulation of genetic relatedness and the loss of genetic diversity in seed crops (KANG, 2001). Genetic parameters such as genetic relatedness, inbreeding, and genetic diversity should be calculated to monitor and determine the genetic diversity of seed crops (BILIR et al., 2002).

The aim of this study was to determine overall variation in clone fertility based on observed strobilus production (good and poor years), to evaluate the parental balance and maleness index for 3 years, and to monitor the genetic diversity of seed crop in a black pine seed orchard. These tasks include estimating status number $(N s)$, relative status number $(\mathrm{Nr})$, and sexual asymmetry $(A s)$. Another aim was to identify the implications of flowering variation for orchard management. Therefore, the objective of this study was to provide genetic information to establish a new black pine seed orchard in Turkey.

\section{Materials and Methods}

\section{Descriptions of seed orchard and data collection}

The work reported here was carried out in the 11.3 ha seed orchard of Bartin (latitude $40^{\circ} 6^{\prime} \mathrm{N}$, longitude $32^{\circ} 15^{\prime} \mathrm{E}$, altitude $100 \mathrm{~m}$ ) located in the northern part of Turkey. The orchard was established in March 1990 and comprises 30 clones (1760 ramets) derived from inten- 
sively selected plus trees in the natural forest of Karabuk-Yenice. Grafts were two years old at the time of establishment and were planted at spacing $8 \times 8 \mathrm{~m}$. (ANONYMOUS, 2001b).

The numbers of female and male strobili were counted from nine ramets chosen randomly from per clone in three consecutive years (2002, 2003 and 2004). Strobili of the sampled ramets were counted individually over the whole crown.

\section{Parental balance and the maleness index}

Parental balance of seed orchard crops is commonly summarized by cone-yield curves (GRIFFIN, 1982). In this method the seed orchard clones are ranked from high to low yield and cumulative percentage calculations are plotted against the number of the clones (CHAISURISRI and EL-KASSABY, 1993).

The maleness index $\left(M_{i}\right)$ is defined as the proportion of a clone's reproductive success that is transmitted through its pollen (KANG, 2000). Maleness index based on strobilus production was estimated (CHOI et al., 2004) as follows;

$$
M_{i}=\frac{m_{i}}{\left(m_{i}+f_{i}\right)}
$$

Where $m_{i}$ and $f_{i}$ are the number of male and female strobili of the $i^{\text {th }}$ clones.

\section{Fertility variation and status number}

Fertility variation measured by the coefficient of variation $(C V)$ and sibling coefficient $(\Psi)$

The coefficient of variation, namely the standard deviation divided by mean as follows:

$$
C V=\frac{s}{M}=\sqrt{\frac{N\left(N \sum_{i=1}^{N} P_{i}^{2}-1\right)}{N-1}}
$$

Where $\mathrm{s}$ is the standard deviation, $\mathrm{M}$ is the mean, $N$ is the number or the clones and $P_{i}$ is the fertility (female or male) of clone $\mathrm{i}$.

The sibling coefficients for female $\left(\Psi_{\mathrm{f}}\right)$ and male $\left(\Psi_{\mathrm{m}}\right)$ were calculated as follows:

$$
\begin{aligned}
& \psi_{f}=N \sum_{i=1}^{N}\left(\frac{f_{i}}{\sum f_{i}}\right)^{2}=C V_{f}^{2}+1 \\
& \psi_{m}=N \sum_{i=1}^{N}\left(\frac{m_{i}}{\sum m_{i}}\right)^{2}=C V_{m}^{2}+1
\end{aligned}
$$

where $\mathrm{N}$ is the census number, $C V_{f}$ and $C V_{m}$ are the coefficients of variation in female and male strobilus production among clones.

Status numbers were calculated based on the fertility variation of female and male parents (LINDGREN et al., 1996), respectively as follows:

$$
N_{s(f)}=\frac{1}{\sum_{i}^{N} f_{i}^{2}}
$$

$$
N_{s(m)}=\frac{1}{\sum_{i}^{N} m_{i}^{2}}
$$

where $N_{s(f)}$ and $N_{s(m)}$ are the status numbers of female and male, respectively.

Status number $\left(N_{s}\right)$ on the total fertility was calculated as follow formula informed by KANG (2001);

$$
N_{s}=\frac{4 N}{\left[\Psi_{f}+\Psi_{m}^{\prime}+2+2 r \sqrt{\left(\Psi_{f}-1\right)\left(\Psi_{m}^{\prime}-1\right)}\right]}
$$

where $\mathrm{r}$ is the correlation coefficient between female and male strobilus production.

\section{Relative status number and group coancestry}

Relative status number on total fertility was calculated as the ratio of status number $\left(N_{s}\right)$ over census number $(N)$ as follows;

$$
N_{r}=\frac{N_{s}}{N}
$$

Status number $\left(N_{s}\right)$ was defined as half the inverse of group coancestry (LINDGREN et al., 1996) as follows;

$$
N_{s}=\frac{0.5}{\Theta} \quad \Theta=\frac{1}{2 N_{s}}
$$

\section{Gene diversity and sexual asymmetry}

Expected gene diversity of seed crops (GD) from firstgeneration seed orchards can be measured relative to the group coancestry of a reference population. GD is a function of group coancestry (LACY, 1995) and inversely proportional to the status number (KANG, 2001) as follows;

$$
G D=1-\frac{1}{2 N_{s}}
$$

The sexual asymmetry $\left(\mathrm{A}_{\mathrm{s}}\right)$ was estimated (KANG and MuLLIN, 2007) as follows;

$$
N_{a}=\frac{N_{s(f)}+N_{s(m)}}{2} \quad A_{s}=\frac{\left(N_{s(c)}-N_{a}\right)}{N_{a}}
$$

where $N s_{(f)}, N s_{(m)}$ and $N s_{(c)}$ are the status numbers of female, male and clone, respectively and $N a$ is the arithmetic mean of the measures $\left(N s_{(f)}\right.$ and $\left.N s_{(m)}\right)$.

\section{Results and Discussion}

\section{Strobilus production}

A large difference was observed between female and male strobili production among clones and years in the black pine seed orchard (Table 1). Most studies have shown that differences in variation between female and male strobili production in others pine species is large (i.e. Aleppo pine, Calabrian pine, Japanese red pine and Scots pine (MatZIRIS, 1997; KeSKIN, 1999; KANG, 2000; NiKkANEN and RUOTSALAINEN, 2000; BiLIR et al., 2004).

Developing a forecast for the effects of tree breeding and conservation operations requires information on variation in fertility (KANG et al., 2003). Fertility varia- 
Table 1. - Averages and coefficients of variation (CV) for female and male strobilus production in the seed orchard calculated for 3 years.

\begin{tabular}{|l|c|c|c|c|c|c|}
\hline Year & \multicolumn{2}{|c|}{2002} & \multicolumn{2}{c|}{2003} & \multicolumn{2}{c|}{2004} \\
\hline Strobili & Female & Male & Female & Male & Female & Male \\
\hline Average & 71.3 & 608.5 & 134.3 & 781.9 & 92.3 & 1014.5 \\
Range & $17.9-149.3$ & $87.4-1615.1$ & $39.4-343.0$ & $47.0-3063.1$ & $32.9-216.8$ & $125.8-4960.1$ \\
CV (\%) & 40.4 & 61.1 & 52.3 & 87.2 & 53.2 & 93.7 \\
\cline { 2 - 7 } r & \multicolumn{2}{|c|}{0.119} & \multicolumn{2}{c|}{-0.008} & \multicolumn{2}{c|}{$-0.463^{* *}$} \\
\hline
\end{tabular}

$\mathrm{r}$, phenotypic correlation coefficient between female and male fertility.

** statistically significant at the 0.01 level $(d f=28)$.

tion among clones provides information about genetic diversity in a seed orchard. In this study, fertility variation was described by the coefficient of variation (CV). As shown in Table 1, the CV for female flowering was lower than the CV for male flowering. KANG et al. (2003) found that fertility differences were slightly larger for males than for females and suggested that a CV of $100 \%$ would be typical in good- or moderate-flowering years for a mature seed orchard. In the present study, the CV of female flowering was $40.4,52.3$, and $53.2 \%$ for the three years; therefore, clonal variation for female flowering was lower. This situation is desirable, and clones in this orchard contributed to female flower production. However, the CVs for male flowering were 61.1, 87.2 , and 93.7, respectively, and were lowest in the poorest-flowering year (2002). This does not agree with the results of a study of Chamaecyparis obtusa (KANG and Mullin, 2007). In that study, fertility variation was lowest in the best-flowering year. In contrast, flowering abundance had a positive impact on CV in the present study, and the highest CV was obtained during the bestflowering year (2004). While male flowering increased, clonal variation also increased, and fewer clones produced a large proportion of all male flowers, so genetic diversity decreased. Therefore, supplemental mass pollination, thinning, or pruning is suggested as an orchard management strategy. Specifically, thinning eliminates clones with low flowering ability (VARGHESE et al., 2000), and pruning maintains a short wide crown, encourages lateral branch growth, and increases flowering (Ho and SCHOOLEY, 1995). Furthermore, better-flowering grafts are favoured as complements to seed orchard management, whereas inferior-flowering grafts are culled when orchards are thinned.

NIKKANEN and VELLING (1987) identified correlations between female and male flowering on the same trees aged 12-15 years. This situation was observed as the orchard age has reached 14 years in the present study. A negative and significant $(p \leq 0.01)$ correlation was found between female and male flowering (Table 1). Although positive correlations between female and male flowering have been reported in Pinus taeda (SchmidtLING, 1983), P. nigra (BILIR et al., 2002), and Picea abies (KJ?R, 1996), negative correlations between female and male flowering were found in Pinus elliottii (SchulTz, 1971), P. sylvestris (SAVOLAINEN et al., 1993), and P. contorta (HANNERZ et al., 2001), as in the present study. The negative correlation between female and male flowering tends to make reproduction more equal among genotypes and reduce total fertility variation (KANG and EL-
KASSABY, 2002). Moreover, this negative relationship could be an important consideration in seed orchard management; some of the best pollen sources may be eliminated if the parents are subjected to intense roguing (DANBURY, 1971; O'REILly et al., 1982; SchMidTLING, 1983). This, in turn, would narrow the genetic base and perhaps reduce the contribution of some of the better genotypes (KANG, 2001).

\section{Parental balance and maleness index}

Parental balance curves for seed orchard crops explain high and low strobili producers; therefore, the maternal and paternal genetic contributions are represented by curves. In this study, the curves presented in Figure 1 represent cumulative gamete contributions. A cumulative contribution curve has often been used to quantify fertility variation in forest populations (GRIFFIN, 1982; El-Kassaby and ReYNOLdS, 1990; AdAMs and KunZe, 1996). In Figure 1, the cumulative percentage calculations were plotted against the total number of clones.

The parental balance curves varied between flowerings and years and did not improve with age. The observed curves for female and male flowering deviated largely from the ideal situation, and the orchard's clones contributed equally to the gamete pool. Therefore, certain clones may consistently produce high or low flowering due to their genetic tendencies. One-third of the clones (10 clones) in the orchard produced $49 \%$ of the total female flowers and $62 \%$ of the total male flowers in the three years. Furthermore, the parental balance curve in 2002, a poor-flowering year, was closer to the ideal than was that in other years. The near-ideal situation was not observed in the best-flowering year (2004). This result was similar to the report by KANG (2000) and BILIR et al. (2002) but was not in agreement with those by CHAISURISRI and El-KASSABY (1993) or ADAMS and KUNZE (1996). In the present study, a negative relationship was found between ramet age and improvement in parental balance, suggesting supplemental mass pollination.

The maleness index was defined as sexual asymmetry of the clones for 3 years and is presented in Figure 2 as the cumulative gamete contribution.

Most studies have shown a 0.8 to 0.2 maleness index (BurczyK and ChAluPKA, 1997; KANG, 2000). A maleness value near 0.5 indicates that female and male fertilities are nearly equal. In this study, the maleness value (0.74) in 2002 was closest to an equal situation. A high maleness value in a clone indicates that the clone is con- 


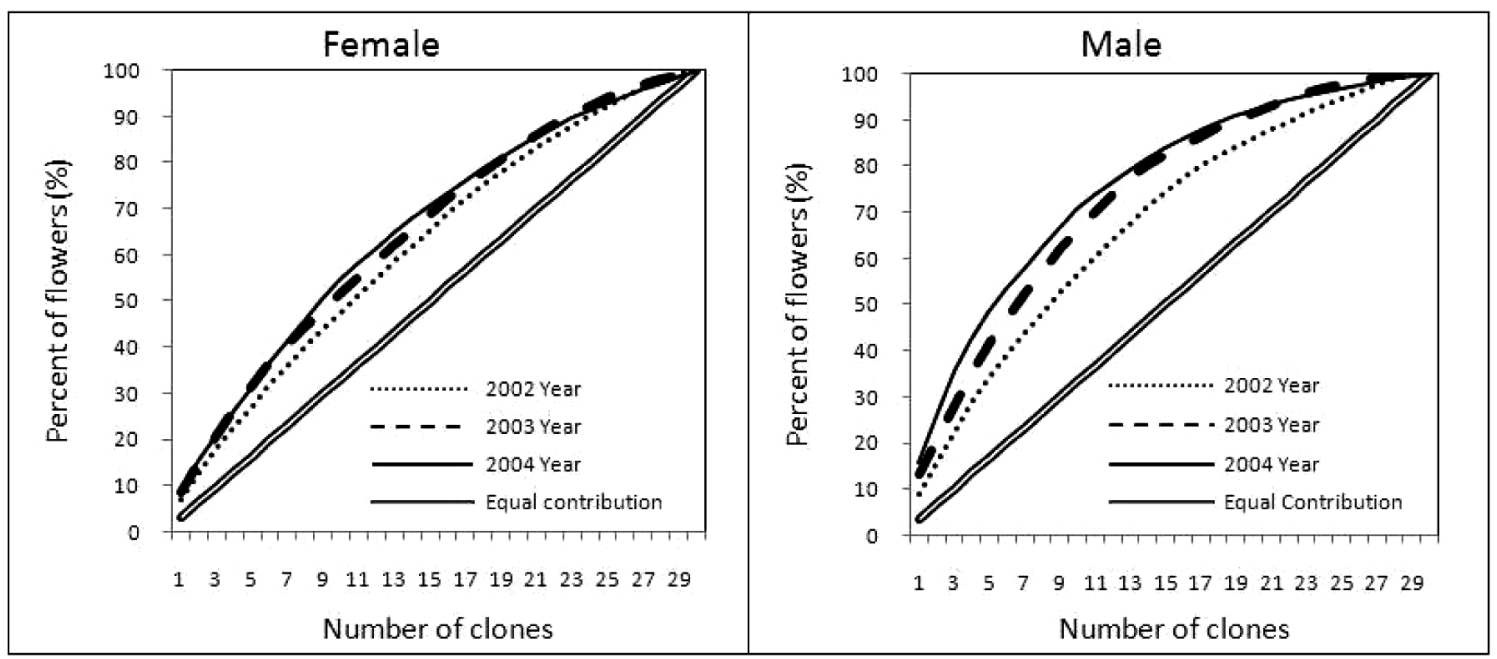

Figure 1. - Parental balance curves of female and male flowers in the seed orchard for 3 years.

tributing more paternally than maternally (CHOI et al., 2004). As shown in Figure 2, the highest maleness index was 0.92 , whereas 0.1 was the lowest in the best-flowering year (2004). Consequently, a high maleness index during the best-flowering year may reflect an increased probability of selfing, because few clones produced most of the male flowers in the orchard. Therefore, sexually asymmetric contributions reduce the proportion of

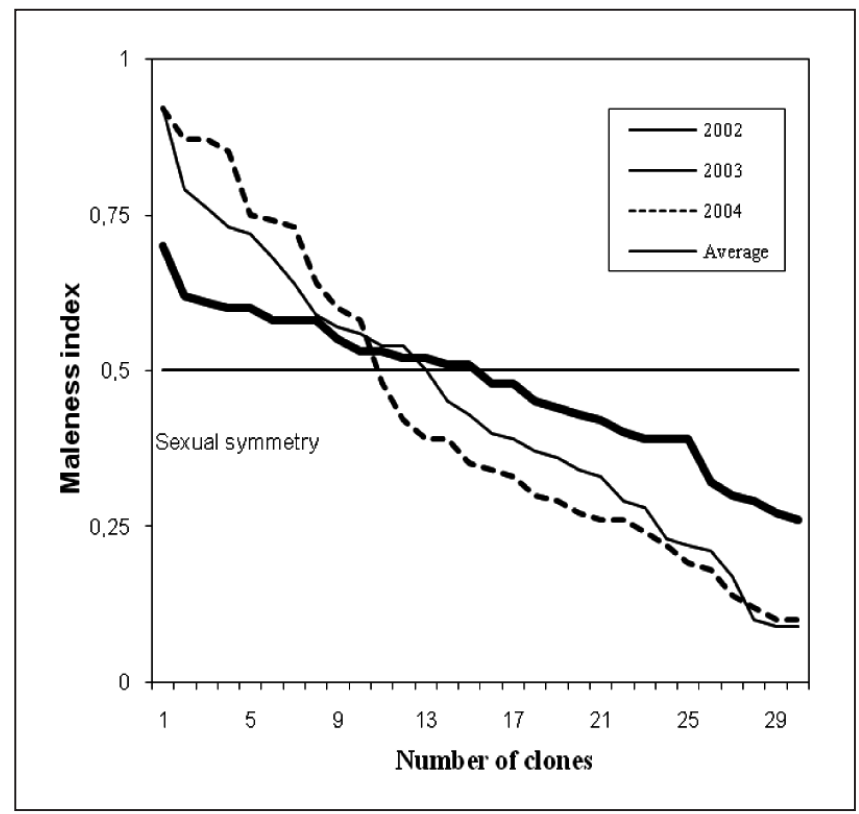

Figure 2. - Maleness index in the orchard for 3 years. homozygotes in an orchard from that expected under the Hardy-Weinberg equilibrium and potentially mask the effects of inbreeding (KANG, 2000). Thus, management activities, such as supplemental mass pollination, cultural or hormonal treatments, or aborting some ramets from high producing clones, should be considered in the orchard.

\section{Fertility variation, status number, and relative status number}

Fertility variation, status number, and relative status number for female and male strobili during the observed years are shown in Table 2.

Fertility variation was estimated by the sibling coefficient $(\psi)$ because $\psi$ relates to orchard crops, and KANG (2001) indicated that $\psi$ may potentially provide genetic information for describing orchard crop genetic diversity that is closer to the seed crop than is CV. In this study, fertility variation $\left(\psi_{\mathrm{f}} \& \psi_{\mathrm{m}}\right)$ varied among years and between genders within years. Female fertility variation $\left(\psi_{\mathrm{f}}\right)$ was lower than was male fertility variation $\left(\psi_{\mathrm{m}}\right)$ in the 3 years. This result was similar to that reported by PRESCHER et al. (2007). Fertility variation for the poorflowering year (2002) was close to one $\left(\psi_{\mathrm{f}}=1.16 \&\right.$ $\psi_{\mathrm{m}}=1.37$ ), implying that orchard clones were expected to make near-equal contributions to the seed crop, as stated by KANG and MULLIN (2007). Generally, fertility variation tends to be small, and the effective number large in good-flowering years (MATZIRIS, 1993; NIKKANEN and RuOTSALAINEN, 2000). However, in this study, the production of strobili and the fertility variation were highest during the best-flowering year (2004) (Table 2).

Table 2. - Fertility variation $\left(\psi_{f} \& \psi_{m}\right)$, status number $\left(N s_{f} \& N s_{m}\right)$, and relative status $\left(N r_{f} \& N r_{m}\right)$ number estimated from female and male strobili production for 3 years.

\begin{tabular}{lcccccc}
\hline Year & \multicolumn{2}{c}{2002} & \multicolumn{2}{c}{2003} & \multicolumn{2}{c}{2004} \\
\hline Strobili & female & male & female & male & female & male \\
\hline$\psi_{\mathrm{f}} \& \psi_{\mathrm{m}}$ & 1.16 & 1.37 & 1.27 & 1.76 & 1.28 & 1.88 \\
$N s_{\mathrm{f}} \& N s_{\mathrm{m}}$ & 25.9 & 22.1 & 23.8 & 17.3 & 23.6 & 16.2 \\
$N r_{\mathrm{f}} \& N r_{\mathrm{m}}$ & 0.86 & 0.73 & 0.79 & 0.58 & 0.79 & 0.54 \\
\hline
\end{tabular}


Status number and relative status number of female parents were higher than those of male parents during the 3 years. Relative status number for male strobili in 2004 was much lower than in other years, suggesting supplemental mass pollination. Status numbers of female and male strobili have slowly decreased from year to year in this orchard, but because the status numbers for flowering and the number of years were larger than 10, the depletion of genetic diversity in the following generation due to genetic drift and fertility variation would be small, as reported by KANG (2001). Consequently, small numbers of clones produce most of the flowering or seed in the orchard, which results in a loss of genetic diversity. KANG et al. (2005) stated that a loss in genetic diversity was expected due to the accumulation of relatedness or fertility variation. Reduction in genetic diversity in seed crops will affect the level of diversity in seedlings and, subsequently, of the plantations.

\section{Sexual asymmetry and genetic diversity}

The degree of sexual asymmetry $(A s)$ between female and male strobili for the 3 years is presented in Table 3 . The degree of sexual asymmetry varied from 0.10 in the poor-flowering year (2002) to 0.20 in the better-flowering year (2004), and it increased as the seed orchard matured.

Table 3. - Group coancestry $(\Theta)$, status number $(\mathrm{Ns})$, relative status number $(\mathrm{Nr})$, sexual asymmetry $(\mathrm{As})$, and genetic diversity $(G D)$ for the gametic gene pool in the seed orchard.

\begin{tabular}{lcccc}
\hline Year & 2002 & 2003 & 2004 & $\begin{array}{c}\text { Combined for the } \\
\text { three years }\end{array}$ \\
\hline$\Theta$ & 0.0189 & 0.0209 & 0.0208 & 0.0194 \\
$N S$ & 26.4 & 23.9 & 24.0 & 25.8 \\
$N r$ & 0.88 & 0.79 & 0.80 & 0.86 \\
$A s$ & 0.10 & 0.16 & 0.20 & 0.17 \\
$G D$ & 0.981 & 0.979 & 0.979 & 0.981 \\
\hline
\end{tabular}

The degree of sexual asymmetry was variable depending on years and may be affected by climatic conditions. DANUSEVICIUS (2002) reported that sexual asymmetry is more highly expressed during years of weak seed yield, but in the present study, the weak-flowering year (2002) had a lower sexual asymmetry value. The degree of sexual asymmetry in this study was similar to that reported in Pinus koreiensis (CHOI et al., 2004). KANG and MulLIN (2007) stated that sexual asymmetry theoretically ranges from zero to one (i.e., $0 \leq A s \leq 1$ ), and that an As value of zero indicates perfect sexual symmetry. In the present study, sexual symmetry during 2002 year was close to perfect, and relative status number and genetic diversity $(G D)$ were their highest value. The expected genetic diversity of seed crops from first-generation seed orchards can be measured relative to the group coancestry of a reference population (KANG, 2001). The relative genetic diversity values, calculated for 3 years, were high in this seed orchard. KANG and LINDGREN (1998) reported that relative genetic diversity (compared to reference populations) was quite high in first-generation seed orchards.
Seed orchards in Turkey have been established with about 30 clones originating from plus trees from a single seed stand, and consequently, the genetic base may be quite narrow. However, first-generation seed orchards are established with a large number of clones, so genetic diversity should be maintained in plantations. The present study identified some problems in this orchard, such as variation in clone flowering contributions, panmictic disequilibrium, and parental unbalance. Variation in fertility can be compensated for by intentionally adjusting the numbers of ramets to manage the orchard. Equal seed harvest or mixing of seeds from consecutive years has been suggested, as mixing seed crops reduce fertility variation. Until studies based on the determined genetic value of clones in Turkish seed orchards are complete, the first-generation seed orchards, which provide a large portion of the seed production, must be protected and maintained.

\section{Acknowledgements}

The author thanks anonymous referees who made useful comments, which helped to improve the manuscript.

\section{References}

ADAms, G. W. and H. A. KunZE (1996): Clonal variation in cone and seed production in Black pine and White spruce seed orchards and management implications. Forestry Chronicle 72: 475-480.

ANONYMus (2001a): Sekizinci bes yillik kalkinma plani, Ormancilik ozel ihtisas komisyonu raporu, Devlet planlama teskilati, Yayin no:2531-OIK:547, Ankara, Turkey.

ANONYMUS (2001b): 2000 yili calisma raporu, 2001 yili calisma programi (Working report of 2000 and working plan of 2001), The Research Directorate of Forest Tree Seeds and Tree Breedings, No:3 (132/7), Ankara, Turkey.

BILIR, N., K. S. KANG and H. ÖZTURK (2002): Fertility variation and gene diversity in clonal seed orchards of Pinus brutia, Pinus nigra and Pinus sylvestris in Turkey. Silvae Genetica 51: 112-115.

BILIR, N. KANG, K. S., ZANG, D. and D. LiNDGREN (2004): Fertility variation and status number between a base population and a seed orchard of Pinus brutia. Silvae Genetica 53: 161-163.

BuRCZYK, J. and W. CHALUPKA (1997): Flowering and cone production variability and its effect on parental balance in a Scots pine clonal seed orchard. Ann. Sci. For. 54: 129-144.

Chaisurisri, K. and Y. A. El-Kassaby (1993): Estimation of contribution to cone and seed crops in a Sitka spruce seed orchard. Ann. Sci. For. 50: 461-467.

CHOI, W. Y., K. S. KANG, S. U. HAN and S. D. HUR (2004): Estimation of heritabilities and clonal contribution based on the flowering assessment in two clone banks of Pinus koraiensis S. et Z. Proc. of IUFRO 2.02.15 (Breeding and genetic resources of five-needle pines). July24-27, 2001, Medford, Oregon, USA. USDA Forest Service Proceeding RMRS-P-32. 2004. p.172-177.

DANBURY, D. J. (1971): Economic implications of selection for seed production in radiata pine seed orchards. Aust. For. Res. 5: 37-44. 
DANUSEviČIUS, J. (2002): Sexual asymmetry in Scots pine seed orchards, Dendrobiology, vol. 47: 83-88.

El-Kassaby, Y. A., A. M. K. FASHLER and M. CROWN (1989): Variation in fruitfulness in a Douglas-fir seed orchard and its effect on crop-management decisions. Silvae Genetica 38: 113-121.

El-Kassaby, Y. A. and S. ReYnolds (1990): Reproductive phenology, parental balance, and supplemental mass pollination in a Sitka-spruce seed orchard. For. Ecol. Manage. 31: 45-54.

El-Kassaby, Y. A. and G. R. Askew (1991): The relation between reproductive phenology and reproductive output in determining the potential gametic pool profile in a Douglas-fir seed orchard. Forest Science 37: 827-835.

El-Kassaby, Y. A. and C. CoOK (1994): Female reproductive energy and reproductive success in a Douglas-fir seed orchard and its impact on genetic diversity. Silvae Genetica 43: 243-246.

EL-KASSABY, Y. A. (2000): Effect of forest tree domestication on gene pools. In: Forest Conservation Genetics: Principles and Practice edited by A. Young, D. BoshieR and T. BOYLE, Commonwealth Scientific and Industrial Research Organization (CSIRO), CABI Publishing, Canberra, Australia. 13: 197-213.

GRIFFIN, A. R. (1982): Clonal variation in radiata pine seed orchards. I. Some flowering, cone, and seed production traits. Aust. For. Res. 12: 295-302.

Hannerz, M., S. N. Aitken, T. ERicsson and C. C. Ying (2001): Inheritance of strobilus production and genetic correlation with growth in Lodgepole pine. Forest Genetics 8: 323-329.

HARJU, A. (1995): Genetic functioning of Scots pine seed orchards. Ph.D. thesis. University of Oulu, Finland. Acta Universitatis Ouluensis 271.

Ho, R. H. and H. O. Schooley (1995): A review of tree crown management in orchards. For. Chron. 71, $311-316$.

KANG, K. S. and D. LindGREN (1998): Fertility variation and its effect on the relatedness of seeds in Pinus densiflora, Pinus Thunbergii and Pinus koraiensis clonal seed orchards. Silvae Genetica 47: 196-201.

KANG, K. S. (2000): Clonal and annual variation of flower production and composition of gamate gene pool in a clonal seed orchard of Pinus densiflora. Canadian Journal of Forest Research 30: 1275-1280.

KANG, K. S. (2001): Genetic gain and gene diversity of seed orchard crops. Ph. D. Thesis. Swedish University of Agricultural Science, Umeå, Sweden. Acta Universitatis Agriculturae sueciae, Silvestria 187. pp. 75.

KANG, K. S. and Y. A. EL-KASSABY (2002): Considerations of correlated fertility between genders on genetic diversity: Pinus densiflora seed orchard as a model. Theor. Appl. Genet. 105: 1183-1189.

KANG, K. S., A. D. BilA, A. M. HARJU and D. LindGRen (2003): Fertility variation in forest tree populations. Forestry 76: 329-344.

Kang, K. S., Y. A. El-Kassaby, M. S. Chung, C. S. Kim, Y. J. KANG and B. S. KANG (2005): Fertility variation and genetic diversity in a clonal seed orchard of Cryptomeria japonica. Silvae Genetica 54: 104-107.

KANG, K. S. and T. J. MULLIN (2007): Variation in clone fertility and its effect on the gene diversity of seeds from a seed orchard of Chamaecyparis obtusa in Korea, Silvae Genetica, 56: 134-137.

KaYA, Z., E. Kun and A. Guner (1997): Turkiye bitki genetik cesitliligin yerinde korunmasi (in-situ) ulusal plani, Milli Egitim Basımevi, Istanbul.

KESKIN, S. (1999): Çameli-Göldağı orijinli kızılçam tohum bahçesinde çiçek ve kozalak verimi açısından klonal farklılıklar ve çiçeklenme fenolojisi, Batı Akdeniz Ormancılık Araştırma Enstitüsü, Teknik Bülten no: 9, Antalya, pp. 96.

KJÆR, E. D. (1996): Estimation of effective population number in a Picea Abies (Karst.) seed orchard based on flower assessment. Scandinavian Journal of Forest Research 11: 111-121.

Koski, V. and J. ANTOLA (1994): National tree breeding and seed production programme for Turkey 1994-2003, Prepared in Cooperation with the Research Directorate of Forest Tree Seeds and Tree Breeding, ENSO Forest Development OY LTD, Turkey.

LACY, R. C. (1995): Clarification of genetic terms and their use in the management of captive populations. Zoo Biology 14: $565-578$.

LindGren, D., L. D. GeA and P. A. Jefferson (1996): Loss of genetic diversity monitored by status number. Silvae Genetica 45: 52-59.

NikKANEN, T. and P. VELLING (1987): Correlations between flowering and some vegetative characteristics of grafts of Pinus Sylvestris, For. Ecol. Manage. 19: 35-40.

NIKKANEN, T. and S. RUOTSALAINEN (2000): Variation in flowering abundance and its impact on the genetic diversity of grafts of Pinus sylvestris. For. Ecol. Manage. 19: 35-40.

MATZIRIS, D. (1993): Variation in cone production in a clonal seed orchard of black pine. Silvae Genetica 42: 136-141.

MATZIRIS, D. (1997): Variation in growth, flowering and cone production in a clonal seed orchard of Aleppo pine grown in Greece. Silvae Genetica 46: 224-228.

O'REILly, C., W. H. PARKER and J. E. BARKER (1982): Effect of pollination period and strobili number on random mating in a clonal seed orchard of Picea mariana. Silvae Genetica 31: 90-94.

Prescher, F., D. Lindgren, C. Almqvist, J. Kroon, T. A. Lestander, T. J. Mullin (2007): Female fertility variation in mature Pinus sylvestris clonal seed orchards. Scandinavian Journal of Forest Research 22: 280-289.

Savolainen, O., K. KarkKainen, A. HarJu, T. NikKanen and M. Rusanen (1993): Fertility variation in Pinus sylvestris: A test of sexual allocation theory. American Journal of Botany 80: 1016-1020.

Schmidtling, R. C. (1983): Genetic variation in fruitfulness in a loblolly pine (Pinus taeda L.) seed orchard. Silvae Genetica 32: 76-80.

Schultz, R. P. (1971): Stimulation of flower and seed production in a young slash pine orchard. U.S. Southeastern For Exp Station USDA Forest Service, SE-91, pp. 10.

Varghese, M., A. Nicodemus, B. Nagarajan, K. R. S. SidDAPPA, S. S. R. BENNET and K. Subramanian (2000): Seedling seed orchards for breeding tropical trees. Scroll Press, Institute of Forest Genetics and Tree Breeding, Coimbatore, India, 126p. 